\title{
Research on the Ways to Cultivate the Innovative Ability of Undergraduates Based on the Degree of Teaching Participation and Satisfaction
}

\author{
Hong ZHAO \\ Tianjin Polytechnic University \\ Tianjin, China \\ zhaohong300160@126.com \\ Yuxin ZHANG \\ Tianjin Polytechnic University \\ Tianjin, China
}

\author{
Shuhong WEN \\ Teaching Quality Supervision and Assessment Center \\ Tianjin Polytechnic University \\ Tianjin, China \\ Shuzhen MEI \\ Teaching Quality Supervision and Assessment Center \\ Tianjin Polytechnic University \\ Tianjin, China
}

\begin{abstract}
The purpose of this paper is to study the ways to cultivate Undergraduates' innovative ability. This paper investigates the current situation of Undergraduates' innovative ability from three dimensions: innovative thinking, innovative wisdom and innovative personality. Based on the analysis of the survey results, it is concluded that students' participation and satisfaction in teaching are the important factors influencing the improvement of College Students' overall innovative ability. Furthermore, based on the degree of participation and satisfaction in teaching, innovative thinking and innovative laboratory are stimulated from the initiation of innovative methods. Specific measures and suggestions to improve Undergraduates' innovative ability are put forward from five aspects: guiding and releasing innovative power, improving students' participation in innovative projects, displaying innovative ability in innovative contests, improving satisfaction and ensuring the effect of incentive and evaluation mechanism. The results of this study will play a guiding role in cultivating Undergraduates' innovative ability.
\end{abstract}

Keywords-Participation;

Satisfaction;

Innovative ability; Undergraduates

\section{INTRODUCTION}

Innovative ability is the ability to use knowledge and theory to continuously provide new ideas, theories, methods and inventions with economic, social and ecological values in the fields of science, art, technology and various practical activities Undergraduate education is an important foundation of modern higher education. At present, China has built the largest education system in the world. About 15 million undergraduates in China are the vital force and important support for public innovation. How about the innovative ability of undergraduates? How to improve the innovative ability of undergraduates? These are related to the progress of the country and the livelihood of the nation.

Undergraduate education is different from primary and

This paper is funded by the key project of Tianjin University Undergraduate Teaching Quality and Teaching Reform Research Program, Research and Practice on the Monitoring and Evaluation System of Undergraduate Teaching Quality of "One, Three, Three, One" in Universities $(171005802 \mathrm{~F})$ secondary education. For undergraduates, they should not only learn textbook knowledge, but also master how to use professional knowledge innovatively in practice. The innovative ability of undergraduates greatly affects the innovative ability of the whole country[1]. In the new era of promoting the connotation development of higher education, the cultivation of College Students' innovative ability is particularly important and urgent.

\section{Processes And Methods}

\section{A. Teaching participation and satisfaction are the important} influencing factors of students' innovative ability

There are many factors influencing undergraduates' innovative ability, such as teaching environment, students' quality, teachers' strength, students' participation in teaching, students' satisfaction with teaching, etc. Whether the degree of teaching participation and satisfaction are the important factors affecting students' innovative ability or not, this study conducted a questionnaire survey on the correlation between the degree of teaching participation, teaching satisfaction and undergraduates' innovative ability. The main contents of the survey include the evaluation of college students' innovative ability, their participation in teaching and their satisfaction. In order to better study the relationship between the three, this study will statistics the results of each student's questionnaire, and then calculate the average of individual teaching participation, teaching satisfaction and innovative ability.

Each student's three indicators are brought into the scatter plot to consider the relationship between the three. The correlation analysis of teaching participation, teaching satisfaction and innovative ability is shown in Fig.1. From the graph, we can see that the three curves of teaching participation, teaching satisfaction and college students' innovative ability have high consistency, which shows that students with high teaching participation and teaching satisfaction have the high corresponding innovative ability, that is, there is a strong positive correlation among the three curves. 


$$
\begin{aligned}
& \text { Teaching participation } \mathrm{An}=\frac{1}{4} \sum f i(\mathrm{i}=1,2,3,4 ; \mathrm{n}=1,2,3 \ldots 106) \\
& \text { Teaching satisfaction } \mathrm{Bn}=\frac{1}{4} \sum f j(j=1,2,3,4 ; \mathrm{n}=1,2,3 \ldots 106) \\
& \text { Innovative ability } \mathrm{Cn}=\frac{1}{8} \sum f k(k=1,2,3 \ldots 7,8 ; \mathrm{n}=1,2,3 \ldots 106)
\end{aligned}
$$

Based on this, this study explores teaching participation and satisfaction as two important factors. Research shows that in order to improve undergraduates' innovative ability, the first thing is to let students participate in teaching, by teaching participation, to improve students' satisfaction with university teaching; If the teaching satisfaction was improved, students are more willing to take the initiative to learn, accompanied by the improvement of undergraduates' innovative ability; after the improvement of innovative ability, students will have more passion to participate in teaching, satisfaction once again improved in the process of teaching participation, so the innovative ability has been improved once more, thus entering a good cycle of undergraduates' innovative ability to continuously improve. The cultivation mode of undergraduates' innovative ability is shown in Fig.2.

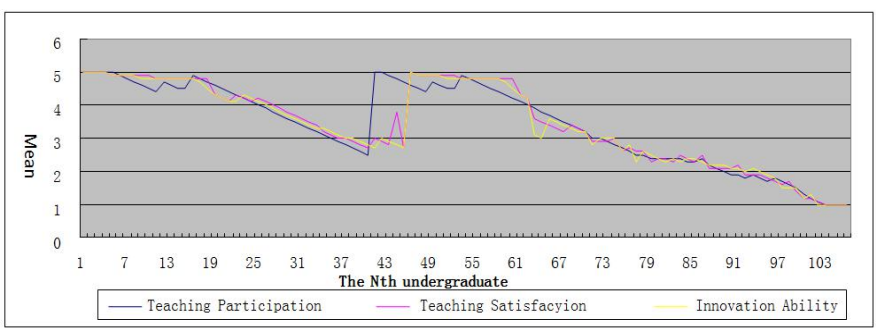

Fig. 1 The correlation analysis of teaching participation, teaching satisfaction and innovation ability

In summary, undergraduates' professional accomplishment has been consolidated, their personal ability has been exercised and their thinking activity has been enhanced in the process of participating in teaching practice. Whether it is the sense of achievement or the sublimation of students' ideological realm brought by the teaching process, in short, for the vast majority of students, participating in the teaching practice process will enable them to better recognize the importance of learning, feel the charm of learning, and have a higher recognition of undergraduate teaching satisfaction[2]. If students have a positive and recognized attitude towards undergraduate teaching, they will be more willing to participate in undergraduate teaching, more involved in teaching and practice, active and more creative to learn and practice, and this process is the best way to improve undergraduate students' innovative ability.

\section{B. Analysis of the current situation of the innovative ability of undergraduates based on the degree of teaching participation and satisfaction}

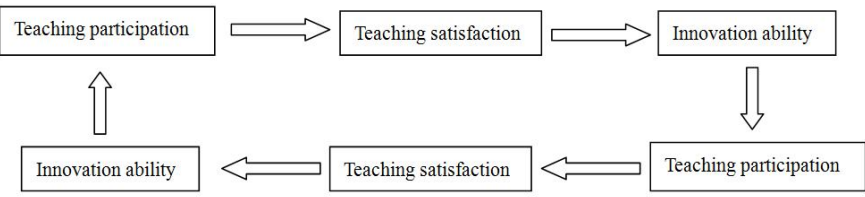

Fig. 2 The cultivation mode of undergraduates' innovative ability

In order to more objectively and accurately reflect the current situation of undergraduates' innovative ability, this study conducts a questionnaire survey and interviews on the evaluation of undergraduates' innovative ability, teaching participation and satisfaction. The survey of undergraduates innovative ability involves nine dimensions of innovative thinking, innovative wisdom and innovative personality, the evaluation of college students' innovative ability is shown in TABLE I; the survey of teaching participation and satisfaction involves eight aspects. the evaluation of teaching participation

\begin{tabular}{|c|c|c|c|c|c|}
\hline Project & $\begin{array}{l}\text { Completely } \\
\text { inconsistent }\end{array}$ & $\begin{array}{c}\text { Mainly } \\
\text { inconsistent }\end{array}$ & $\begin{array}{c}\text { Nothing } \\
\text { special }\end{array}$ & $\begin{array}{c}\text { Mainly } \\
\text { consistent }\end{array}$ & $\begin{array}{c}\text { Completely } \\
\text { consistent }\end{array}$ \\
\hline \multicolumn{6}{|l|}{$\begin{array}{l}\text { When I do things, my mind is always clear and fluent, } \\
\text { and I often have new ideas. }\end{array}$} \\
\hline \multicolumn{6}{|l|}{$\begin{array}{l}\text { When I do things, I am good at putting forward different } \\
\text { ideas. }\end{array}$} \\
\hline \multicolumn{6}{|l|}{ I like creative activities and participate in them actively. } \\
\hline \multicolumn{6}{|l|}{ I have extensive and solid knowledge. } \\
\hline \multicolumn{6}{|l|}{ I have agile thinking and rational judgment. } \\
\hline \multicolumn{6}{|l|}{ I've had some great innovative experiences. } \\
\hline \multicolumn{6}{|l|}{ I have a lasting interest in new or unclear things. } \\
\hline \multicolumn{6}{|l|}{ I am filled with thirst for knowledge and curiosity. } \\
\hline $\begin{array}{l}\text { I can stick to what I like and what I am interested in for a } \\
\text { long time. }\end{array}$ & & & & & \\
\hline
\end{tabular}
and satisfaction is shown in TABLE II.

TABLE I. EVALUATION TABLE OF COLLEGE STUDENTS' INNOVATIVE ABILITY

This questionnaire survey takes students, counselors, teachers and managerial cadres of more than 10 undergraduate universities in Tianjin as research objects. (questionnaire survey for students, interviews for others). From three levels of innovative thinking, innovative wisdom and innovative personality, the current undergraduates' innovative ability is judged. The results are as follows:
1) The innovative ability of undergraduates is relatively low and needs to be strengthened urgently.

The analysis of the importance of undergraduates' innovative ability is shown in fig.3. Among the respondents, $88.11 \%$ thought that the cultivation of undergraduates' innovative ability was very important, it was agreed that the cultivation and improvement of undergraduates' innovative ability should be strengthened. As for the current situation of college students' innovative ability, only 3\% think that their 
innovative ability is very strong, 24\% think that their innovative ability is very low, $27 \%$ think that they are low, $35 \%$ think that they are general. The analysis of the current situation of undergraduates' innovative ability is shown in fig.4. This shows that it is generally believed that Chinese undergraduates' innovative ability is relatively low and that students are not confident enough about their innovative ability.

2) The innovative ability of science and engineering students is higher than that of literature and history students.
The average level of innovative ability of students of different majors is different. The questionnaire shows that the average score of the innovative ability of students of science and engineering is 3.8 , and that of students of literature and history is 2.5. It shows that the innovative ability of students of science and engineering is higher than that of students of literature and history. In the process of interviewing teachers and staff, they also agree that undergraduates majoring in science and engineering have stronger practical ability and are more willing to spend time thinking and innovating.

TABLE II. EVALUATION TABLE OF TEACHING PARTICIPATION AND SATISFACTION

\begin{tabular}{|c|c|c|c|c|c|}
\hline Project & $\begin{array}{l}\text { Completely } \\
\text { inconsistent }\end{array}$ & $\begin{array}{c}\text { Mainly } \\
\text { inconsistent }\end{array}$ & $\begin{array}{l}\text { Nothing } \\
\text { special }\end{array}$ & $\begin{array}{c}\text { Mainly } \\
\text { consistent }\end{array}$ & $\begin{array}{c}\text { Completely } \\
\text { consistent }\end{array}$ \\
\hline \multicolumn{6}{|l|}{ Initiative to ask questions or participate in discussions in class } \\
\hline \multicolumn{6}{|l|}{ Are you satisfied with the atmosphere of College classes? } \\
\hline \multicolumn{6}{|l|}{ Actively participate in teacher's research } \\
\hline \multicolumn{6}{|l|}{$\begin{array}{l}\text { Are you satisfied with the subjects that university teachers have } \\
\text { done? }\end{array}$} \\
\hline \multicolumn{6}{|l|}{$\begin{array}{l}\text { Actively participate in various academic, professional or } \\
\text { technical competitions }\end{array}$} \\
\hline \multicolumn{6}{|l|}{$\begin{array}{l}\text { Are you satisfied with the academic, professional or technical } \\
\text { competitions currently held in universities? }\end{array}$} \\
\hline \multicolumn{6}{|l|}{ Actively participate in academic lectures, forums, salons, etc. } \\
\hline $\begin{array}{l}\text { Are you satisfied with the lectures, forums, salons and so on that } \\
\text { are being held in the university? }\end{array}$ & & & & & \\
\hline
\end{tabular}

3) The innovative ability of student cadres is superior to that of ordinary students.

In this survey, we use the method of correlation casting. Statistical results show that the innovative ability of student cadres surveyed in more than ten universities is more than 3.9 (significantly higher than the average of the survey of 3.1). Student cadres are enthusiastic about participating in various campus activities, competitions and innovative practices. Their participation in teaching is obviously better than that of ordinary students, and their innovative ability is relatively higher.

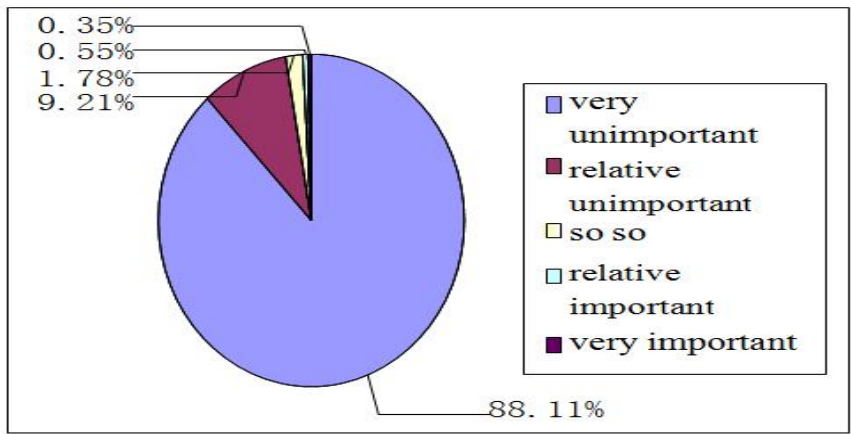

Fig. 3 The importance of the innovative ability of undergraduates

\section{Effective ways to improve undergraduates' innovative ability}

Innovation can be stimulated in some ways. The degree of participation and satisfaction in teaching should be improved to cultivate undergraduates' innovative ability, thus to improve the overall innovative ability of college and university students Specific measures including five aspects: using innovative methods to stimulate innovative thinking, strengthening innovative laboratories guidance to release innovative impetus, improving students' participation in innovative projects, displaying innovative ability in innovative contests, and making scientific and reasonable incentive and evaluation mechanism. More precisely:

1) Using innovative methods to stimulate innovative thinking

Undergraduates, who stand out through China's tough college entrance examination competition, have outstanding learning and thinking ability. Most undergraduates have certain innovative ability, but there are few media to inspire them. Therefore, the first step to cultivating innovative ability is to inspire undergraduates' innovative thinking. Firstly, universities should offer courses on innovative methods [3], which teach students what is innovative thinking, how to cultivate innovative ability and how to innovate. Secondly, universities should take innovative thinking stimulation in classroom teaching. Teachers should pay attention to the cultivation of students' innovative ability and encourage them to find various innovative methods in the teaching process.

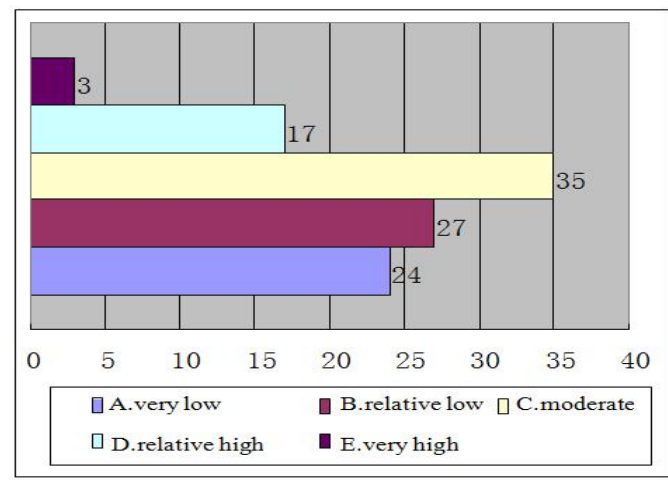

Fig. 4 Current situation of undergraduates' innovative ability 
2) Strengthening innovative laboratories guidance to release innovative impetus

For some undergraduates, they may be lack of innovative consciousness, while others do have innovative consciousness. But some are lack of initiative, so measures should be adopted to help them. Thus, innovative laboratories need to be offered as well as courses on innovative methods to make students have the suitable condition to release innovative ability after their innovative thinking and potency are stimulated in the learning process.

Innovative laboratories can be divided into two groups: (a) comprehensive innovative laboratories, which provide practice space for students' innovative courses; and (b) professional innovative laboratories, which provide a place for undergraduates' professional innovation. The comprehensive innovative laboratory is the continuation of courses on innovative methods. The comprehensive innovative laboratory can provide practice space for students after their innovative thinking is stimulated by learning specialized courses on innovative methods. The professional innovative laboratory is a practice platform for specific undergraduate majors. Necessary mechanical equipment, experimental equipment, drugs, and so on should be provided for students in science and engineering field, thus to provide sufficient hardware conditions for their innovation in professional fields. Props and sites needed for business simulation should be provided for the students majored in economic management, so that they can walk through virtually to improve students' business skills.

3) Carrying out various innovative projects to improve students' participation degree

Innovative methods training will stimulate students' innovative thinking, and innovative laboratories provide practice space for students' innovative activities. Meanwhile, real innovative behavior and the formation of innovative habit need innovative project practice. Universities should start some innovative projects with special features to provide all kinds of innovative project practice opportunities for students [4]. These projects includes: (a) research learning innovative projects related to majors, such as teacher's research project recruitment plan, teacher-student cooperative innovative development project and summer (winter) camp program for inspire innovation; and (b) exploratory practical innovative project which is closely integrated with social practice, such as field research on rural education; and (c) extended operational innovative project on the basis of students' interests and hobbies, such as undergraduate innovative program.

4) Displaying innovative ability in innovative contests to improve satisfaction

Innovative projects will help to train undergraduate students' innovative ability in learning, practice and operation, while innovative contests provide students the chance to display their innovative ability. Innovative competition can also drive more innovative activities and behaviors [5] . Students will be more willing to innovate and may generate more innovative ideas in the process of participating in the innovative competition. We can be sure that the atmosphere of the innovative competition will motivate more undergraduates to participate in innovative activities, whether by its influence on competitors' classmates or the audience. Like innovative projects, innovative competitions can also be divided into three categories: (a) professional innovative competition, such as foreign trade tracking competition for students of foreign trade major, mathematical modeling contest for students of mathematics major, and robot competition for students of mechanical \& electronic engineering major; and (b) practical innovative competition, such as energy conservation and emission reduction competition and research on the current situation of agriculture, rural areas and farmers competition, and (c) interest-based innovative competition, such as psychodrama competition and campus singer competition.

5) Making a scientific and reasonable incentive and evaluation mechanism to guarantee the results

Colleges and universities should not only encourage students to innovate, but also guide students to innovate and reward innovative behaviors [6]. In order to bitterly improve the innovative ability of undergraduates through the above ways, on the one hand, schools should guide students to realize that strong professional knowledge, innovative spirit and innovation and entrepreneurship ability is not only what schools encourage them to own but also what the society needs mostly; on the other hand, colleges and universities should set up the necessary incentive mechanism, such as linking students' innovation ability with the evaluation of awards and merit (such as scholarships), so as to encourage students to innovate in life, study and practice.

TABLE III. EVALUATION INDEX SYSTEM OF THE INNOVATIVE ABILITY OF UNDERGRADUATES

\begin{tabular}{|c|c|l|}
\hline $\begin{array}{c}\text { Evaluation } \\
\text { project }\end{array}$ & First index & \multicolumn{1}{c|}{ Secondary index } \\
\hline \multirow{4}{*}{$\begin{array}{c}\text { Comprehensive } \\
\text { evaluate }\end{array}$} & $\begin{array}{c}\text { Course } \\
\text { Innovation }\end{array}$ & Course participation \\
\cline { 2 - 3 } & $\begin{array}{c}\text { Innovation } \\
\text { training }\end{array}$ & Subject creativity \\
\cline { 2 - 3 } & $\begin{array}{c}\text { Innovative } \\
\text { projects }\end{array}$ & The activity of innovation training \\
\cline { 2 - 3 } & \multirow{2}{*}{$\begin{array}{l}\text { Innovation } \\
\text { competition }\end{array}$} & $\begin{array}{l}\text { Achievement conversion of } \\
\text { innovative projects }\end{array}$ \\
\cline { 2 - 3 } & $\begin{array}{l}\text { Participation of Innovation } \\
\text { competition }\end{array}$ \\
\cline { 2 - 3 } & $\begin{array}{l}\text { achievement of Innovation } \\
\text { competition }\end{array}$ \\
\hline \multirow{2}{*}{ Self-evaluation } & Innovation ability & Comprehensive Innovation ability \\
\cline { 2 - 3 } & $\begin{array}{l}\text { The level of innovation ability } \\
\text { improvement in the year }\end{array}$ \\
\hline
\end{tabular}

At the same time, colleges and universities should evaluate students' innovation ability scientifically. On the one hand, it is convenient to know students' innovation ability and take corresponding measures in time. On the other hand, it can make students have a relatively objective and clear cognition of their innovation ability, and motivate students to participate in innovation activities. The evaluation index system of undergraduate innovation ability should include two parts: comprehensive evaluation and self-evaluation index, the evaluation index system innovation ability of undergraduates is shown in TABLE III. 


\section{CONCLUSION}

This paper draws the conclusion that students' participation and satisfaction in teaching are important factors affecting the improvement of college students' overall innovation ability through questionnaire survey, and then puts forward effective ways to improve undergraduates' innovation ability from five aspects: innovation method, innovative laboratory, innovative project, innovative contest and incentive evaluation mechanism. The results of this study will play a guiding role in cultivating undergraduates' innovative ability.

\section{REFERENCES}

[1] Wang Yidong. "Problems and Countermeasures of improving the practical ability of innovation and Entrepreneurship of college students in China". Quality Education in West China, p.81, 2017.
[2] Xue Ju. "Study on the Mechanism of Job Participation Affecting Young Scientists'Occupational Satisfaction", Master's Degree Thesis of Nanjing University of Technology. Jan. 2013.

[3] Yang Xiudong. "Strategies for Promoting College Students'Innovative and Entrepreneurial Ability". China Adult Education, pp.79-81, Feb. 2018.

[4] Lu Ying, Li Jungang, "Wu Mingzhong, Zhuang Minghui, Golden Swordsman. Ways to Improve College Students'Innovative Ability". Economist, pp.211-212, Jan. 2018 .

[5] Chen Haixuan, Sun Yuejun. "Strategies for enhancing innovation and entrepreneurship ability of local applied undergraduate students under the new situation". Modern Economic Information, pp. 366-367, Nov. 2017.

[6] Chen Xiaofeng. "Research and Countermeasure on Promoting College Students'Scientific and Technological Innovation Ability in the New Era “. Brand Research, pp.195-197, May 2018. 